\title{
PHOTOMETRIC MICRODETERMINATION OF HUMAN GAMMA GLOBULIN. I. DEVELOPMENT OF A QUANTITATIVE FLOCCULATION-NINHYDRIN PROCEDURE ${ }^{1}$
}

\author{
BY ABRAHAM SAIFER AND MICHAEL C. ZYMARIS \\ (From the Biochemistry Department of the Division of Laboratories, Jewish Sanitarium and \\ Hospital for Chronic Diseases, Brooklyn, N. Y.)
}

(Submitted for publication April 23, 1951; accepted October 1, 1951)

There are three general categories of procedures employed for the quantitative determination of the gamma globulin content of biological fluids. These are (1) electrophoretic methods, (2) chemical procedures, usually based on salt or organic solvent precipitation, and (3) immunochemical methods.

A fourth class of procedures which are qualitative or semi-quantitative in nature, are the "protein flocculation reactions." These flocculation procedures are widely used in clinical work to determine changes in protein composition of disease sera, especially in gamma globulin, as compared to normal sera (1).

The application of the electrophoretic technique of Tiselius to biological and medical problems has been fully discussed in recent review articles by Stern and Reiner (2), Luetscher (3) and Gutman (4). From a clinical viewpoint electrophoretic methods have the disadvantages of requiring relatively large amounts of protein material, expensive equipment, and skilled technical help and then permit only a few individual determinations to be performed daily. However, they remain the standard procedure against which other simpler methods are generally compared in the quantitative estimation of a protein fraction.

In recent years three separate salt fractionation procedures have been proposed for the determination of gamma globulin in sera and have been used in clinical investigative work. The methods of Jager and Nickerson (5), Wolfson and his associates (6) and Kibrick and Blonstein (7) have the advantages of requiring relatively small amounts of serum, i.e., 0.5 to $1.0 \mathrm{ml}$.; of determining the gamma globulin directly on the precipitate obtained by salt fractionation with either am-

1 Presented before the Division of Biological Chemistry of The American Chemical Society at the 119th meeting, Boston, Mass., April 15, 1951. monium or sodium sulfate; and of then determining its protein content with a colorimetric biuret procedure. The method of Wolfson and his coworkers (6) has been converted into an even simpler turbidimetric method by de la Huerga and Popper (8), and compared by them (9) to the zinc sulfate and the electrophoretic procedures for gamma globulin. However, recovery experiments with added gamma globulin show a range of $73 \%$ to $92 \%$ with average values of about $85 \%$, which are unsatisfactory results for a quantitative procedure $(6,8)$.

A number of experimenters have employed alcohol-water mixtures at low temperatures and controlled $\mathrm{pH}$ to separate out various protein fractions from human plasma. Pillemer and Hutchinson (10) have employed methanol-water mixtures with acetate buffers to obtain albumin-globulin ratios which conform closely to those obtained with electrophoretic techniques. The most widely used procedures of this kind are the ethanolbuffer methods developed by Edsall (11) and by Cohn and his associates (12-15). Their later procedures are applicable for work with a few milliliters of serum $(16,17)$ and are especially useful in animal protein fractionation studies, e.g., rat (18), dog (19), and guinea pig (20), where electrophoretic analyses are generally unsatisfactory.

From a clinical viewpoint such procedures are also unsatisfactory in that they require large amounts of blood, i.e., 5 to $20 \mathrm{ml}$. of plasma, and additional expensive equipment, such as refrigerated centrifuge or water bath; recover less than $90 \%$ of the gamma globulin present electrophoretically; and necessitate involved and time-consuming techniques for the isolation and quantitative measurement of any particular component, e.g., gamma globulin.

A number of investigators $(21,22)$ have proposed the use of immunochemical procedures for 
determining gamma globulin in human sera. Such procedures are truly microprocedures in that they can determine 30 to $1,000 \mu \mathrm{g}$. of protein accurately and are used to determine quantitatively the gamma globulin content of cerebrospinal fluid as well as sera (22).

The disadvantages of the immunochemical procedure are the involved procedures needed for the preparation and assay of the antisera used, the use of a refrigerated centrifuge and the technical skill and the time required for the involved analyses. In addition Jager and his coworkers (23) have found that the immunological method yields abnormally high values for serum gamma globulin as compared to electrophoretic results.

It is because of the difficulties encountered in the aforementioned procedures for clinical work that Kunkel (24) attempted to use a protein flocculation procedure, i.e., zinc sulfate turbidity, as a quantitative measure of serum gamma globulin content. In contrast to the results obtained by Kunkel (24), de la Huerga, Popper, and coworkers (9) report that zinc sulfate turbidity values do not correlate well with either electrophoresis or the protein content of the centrifuged zinc-protein precipitates. They attribute this to the influence of albumin and lipid intake on the zinc sulfate turbidity. These findings were confirmed by Schmid (25) who found that there was no direct relationship between the gamma globulin fraction and the zinc turbidity value when the salt fractionation method of Jager and Nickerson (5) was used to measure the gamma globulin. The lack of correlation encountered in disease cases, where electrophoretic gamma globulin values are known to be high (e.g., multiple myeloma), was even more striking.

Saifer (26) applied the Hanger cephalin-cholesterol flocculation reaction (27) to the semiquantitative determination of the minute amounts of increased gamma globulin present in cerebrospinal fluid in disease cases. In qualitative studies with Cohn's protein fractions, it was shown that flocculation occurs, with the cephalin-cholesterol emulsion in the presence of Hayem's solution (28), with some of the fractions (for instance, fibrinogen or gamma globulin) but not with others (e.g., albumin) under the stated experimental conditions.

The present paper deals with the quantitative aspects of this reaction from the viewpoint of de- termining the experimental conditions under which gamma globulin could be flocculated out of solution quantitatively and the protein content of the complex measured by the ninhydrin reaction of Moore and Stein (29). The effect of the presence of each of the other protein fractions, which together constitute the whole plasma, on the flocculation method for gamma globulin was also investigated quantitatively. This permitted a separation of the fractions into interfering and non-interfering ones and, with the aid of the electrophoretic data, the working out of simple salt fractionation techniques for the elimination of the interfering fractions in applying the method to the microdetermination of serum gamma globulin.

\section{EXPERIMENTAL}

\section{A. Reagents and apparatus}

1. Sodium chloride. $0.85 \%$ solution.

2. Phosphate buffer $(\mathrm{pH} 7.00)-0.4 \mathrm{M}$. Dissolve $39.2 \mathrm{~g}$. anhydrous $\mathrm{Na}_{2} \mathrm{HPO}_{4}$ and $20.5 \mathrm{~g} . \mathrm{KH}_{2} \mathrm{PO}_{4}$ in a liter of solution. Adjust $\mathrm{pH}$ to $7.00 \pm 0.02$ with a $\mathrm{pH}$ meter.

3. Hayem's solution, modified (29). Dissolve $10.0 \mathrm{~g}$. $\mathrm{NaCl}, 11.0 \mathrm{~g} . \mathrm{Na}_{2} \mathrm{SO}_{4}$ (anhydrous) and $2.5 \mathrm{~g} . \mathrm{HgCl}_{2}$ in a liter of solution.

4. Cephalin-cholesterol emulsion. Prepared from the commercial product supplied by Difco Laboratories, Inc., Detroit, Michigan, according to Hanger (27), as follows: Heat 35 volumes of distilled water in an Erlenmeyer flask to $65^{\circ} \mathrm{C}$. Add to the water 1 volume of the ether solution of the cephalin-cholesterol solution, drop by drop with constant agitation, until a homogeneous emulsion is formed. Continue heating the emulsion on a hot plate, at just below the boiling point with occasional shaking, until 30 volumes of the emulsion remain. Cool to room temperature before using. In these experiments a fresh batch of emulsion was prepared for each day's run.

5. Gamma globulin standard solution. ${ }^{2}$ Weigh out approximately $60 \mathrm{mg}$. of gamma globulin (Cohn's Fraction II) ${ }^{3}$ into a wide-mouth $125 \mathrm{ml}$. glass bottle. Add $50 \mathrm{ml}$.

2 Electrophoretically pure gamma globulin for use as a standard in this procedure may be easily prepared by the ammonium sulfate fractionation method of Kendall as described in the textbook, "Experimental Immunochemistry," by Kabat, E. A., and Mayer, M. M.; Charles C Thomas, Springfield, Ill., 1948, p. 461.

3 Obtained from the University Laboratory of Physical Chemistry of the Harvard University Medical School through the courtesy of Doctors J. T. Edsall and L. D. Wojick. Fractions Lilly II-1 and Squibb 652 (98-99\% gamma globulin) were used in these runs. Fractions used in these experiments were prepared by the older fractionation procedure known as Method 6 . Those prepared by the newer Method 10 (15) are apt to contain glycine as a contaminant and must be dialyzed before use. 
of $0.85 \% \mathrm{NaCl}$ under vacuum conditions, slowly and with constant agitation until most of the protein goes into solution. Centrifuge off any insoluble material at about 3,000 r.p.m. and transfer the clear supernatant fluid to a glass stoppered bottle. Keep in an icebox at $4^{\circ}$ when not in use. The exact protein content of this solution was determined for each day's run by a micro-Kjeldahl digestion and distillation method (30) and diluted with saline to a concentration of about $400 \mu \mathrm{g}$. per $\mathrm{ml}$. The optical density values for the standard gamma globulin solution were obtained with $0.00,0.25,0.50$, and $1.00 \mathrm{ml}$. aliquots, in quadruplicate, without prior flocculation, by the photometric ninhydrin procedure described below, simultaneously with each flocculation run so as to establish the level at which the flocculation method gave quantitative results.

6. Ether-reagent grade, anhydrous.

7. Sodium hydroxide solution- $0.1 \mathrm{~N}$.

8. Ninhydrin reagent. The ninhydrin used in these experiments was obtained from the Dougherty Chemical Company, Jamaica, New York, and twice recrystallized as described by Moore and Stein (29).

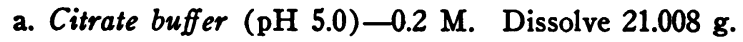
citric acid, reagent, and $200 \mathrm{ml}$. of $1 \mathrm{~N} \mathrm{NaOH}$ in 500 $\mathrm{ml}$. of solution in a volumetric flask. Add a few crystals of thymol as a preservative.

b. Ethylene glycol monomethyl ether (methyl cellosolve). It was generally found necessary to purify the product obtained from commercial sources by distillation under vacuum to prevent turbid solutions.

c. Ninhydrin solution. Dissolve $68 \mathrm{mg}$. of anhydrous stannous chloride (Flaked Stannochlor, 4 obtained from Metal and Thermit Corporation, New York, N. Y.) in $50 \mathrm{ml}$. of citrate buffer in a $100 \mathrm{ml}$. glass stoppered graduated cylinder. Add to this solution $2.0 \mathrm{~g}$. of recrystallized ninhydrin and then $50 \mathrm{ml}$. of the purified methyl cellosolve. Stopper and dissolve by shaking until all the salt is dissolved. A play of colors occurs during the solution process but the final reagent has a pale yellow color and is water clear. If the solution remains turbid it can usually be clarified by placing the graduate and its contents in warm water. A sufficient amount of this reagent was prepared for each day's run.

9. Diluent solution. Mix equal volumes of water and n-propanol, reagent.

10. Water bath, constant temperature, $37.5^{\circ}$.

11. Kahn racks.

12. Centrifuge.

13. Pan, aluminum, large $12^{\prime \prime} \times 18^{\prime \prime} \times 4^{\prime \prime}$ deep, for boiling water bath.

4 When Stannochlor is used in the preparation of the ninhydrin solution in place of the usual reagent $\mathrm{SnCl}_{2}$. $2 \mathrm{H}_{2} \mathrm{O}$, and the solution prepared exactly as described above, it was found that very low and consistent blanks were obtained on day-to-day runs and that no dark colors developed in the solution on prolonged standing even in the presence of air. There is, however, a decrease in color density per unit weight of protein on long standing.
14. Spectrophotometer, Model B Beckman or other similar instrument adaptable for reading small test tubes.

15. Test tube, cuvettes, selected-Select $75 \times 12 \mathrm{~mm}$. o.d. test tubes, pyrex, without lip, for light absorption characteristics in a manner similar to that described in the paper by Moore and Stein (29).

\section{B. Procedure for the quantitative determination of elec- trophoretically pure gamma globulin (Cohn's Fraction II)}

1. Pipette $0.00 \mathrm{ml}$., $0.25 \mathrm{ml}$., $0.50 \mathrm{ml}$., $0.75 \mathrm{ml}$. and 1.00 ml. of the standard gamma globulin solution (Fraction II) in quadruplicate, into the selected test tubes, $75 \times 12$ mm., and then add $0.85 \% \mathrm{NaCl}$ so that the volume in each tube is $1.00 \mathrm{ml}$. Add $0.5 \mathrm{ml}$. of the phosphate buffer (pH 7.00) to each tube, followed by $0.75 \mathrm{ml}$. of the Hayem's solution and $0.75 \mathrm{ml}$. of the cephalin-cholesterol emulsion. ${ }^{5}$ Mix the contents of each tube by inverting twice, replace in the Kahn racks and place the racks in a water bath at $37.5^{\circ}$ for 45 minutes. Centrifuge for $15 \mathrm{~min}$ utes at 3,000 r.p.m., using multiple carriers, pour off supernatant fluid, invert tubes in the racks and allow to drain on to cotton gauze placed on the bottom of the racks. Break up the precipitate by tapping the bottom of the tube and add approximately $2 \mathrm{ml}$. of ether using a 10 or $20 \mathrm{ml}$. glass syringe. Mix well to wash the precipitate and centrifuge again at 3,000 r.p.m. for five minutes. Aspirate off ether layer carefully without disturbing the protein layer with gentle suction, using a glass pipette drawn out to about a $1 / 16$ inch opening. Repeat washing, centrifugation and aspiration once more. Remove all traces of ether by placing racks with the tubes in the $37.5^{\circ}$ water bath for an hour or longer.

2. Quantitative determination of protein content with photometric ninhydrin procedure. Add to each tube 1.0 ml. of $0.85 \% \mathrm{NaCl}$ and $0.2 \mathrm{ml}$. of $0.1 \mathrm{~N} \mathrm{NaOH}$ and mix by shaking the rack with the tubes. Add $0.5 \mathrm{ml}$. of the freshly prepared ninhydrin reagent to each tube, mix the contents well by tapping and place the rack with the tubes in a vigorously boiling water bath for exactly 30 minutes. Mix the contents of each tube by tapping at the end of each 10 minute interval during the heating process. After removal of racks from the water bath allow to cool to room temperature. Add $1.5 \mathrm{ml}$. of the n-propanol-water diluent to each tube, mix the contents well and centrifuge at 2,000 r.p.m. for five minutes to remove any insoluble material. Clean the outside surface of each tube well and measure the optical density values in a spectrophotometer at $570 \mathrm{~m} \mu$, directly in the test tubes, against pure diluent as the blank.

A Beckman Model B spectrophotometer and a Coleman Junior spectrophotometer with test tube adapters were used in these experiments. The results obtained in this run are shown graphically in Figure 1.

5 Where large numbers of determinations are to be performed we have found the Cornwall Automatic pipetting units, as recommended in the paper by Dern and Pullman (31), to be both rapid and accurate for the delivery of a constant volume of a solution. 
Gamma globulin subfractions II-1, II-2 and II-3 were run in an identical manner and these results are also included in Figure 1.

C. Studies of factors which influence the quantitative flocculation of gamma globulin from solution

1. Effect of variation of amount of phosphate buffer $(0.1 M)$. To a series of selected test tubes was added a constant amount of a standardized gamma globulin solution. To each set of four tubes then was added the amount of $0.1 \mathrm{M}$ phosphate buffer ( $\mathrm{pH} 7.00 \pm .02)$ given by each point in Figure 2. The gamma globulin content for the different buffer concentrations was then determined by the quantitative flocculation-ninhydrin procedure exactly as described above.

The results obtained in this run are shown in Figure 2. It is clear that buffer concentration is an important factor in determining whether quantitative flocculation of the gamma globulin takes place. An amount of buffer corresponding to $1.5 \mathrm{ml}$. of $0.1 \mathrm{M}$ phosphate buffer or greater gave satisfactory quantitative results. In order to reduce the volume of solution used, $0.5 \mathrm{ml}$. of a $0.4 \mathrm{M}$ phos- phate buffer, $\mathrm{pH} 7.00 \pm .02$ was employed in all subsequent runs.

2. Effect of variation of the amount of Hayem's solwtion. The variation of this component was studied in a similar manner as was the phosphate buffer described in C. 1 above. The results obtained in this run are described graphically in Figure 3.

It should be noted from these data that practically no flocculation occurs in the absence of the Hayem's solution and in the presence of the cephalin-cholesterol emulsion. The method yields quantitative results in the presence of $0.75 \mathrm{ml}$. or greater of the Hayem's solution.

3. Effect of the variation of the amount of cephalincholesterol emulsion. The variation of this component was studied in the same manner as were the other two components described above. The results obtained in this run are shown graphically in Figure 4.

A considerable amount of the gamma globulin is flocculated out of solution even in the absence of the emulsion but in the presence of the Hayem's solution. The best quantitative result is obtained at about $0.75 \mathrm{ml}$. of the emulsion with slightly decreasing gamma globulin values when greater amounts of the emulsion are used.

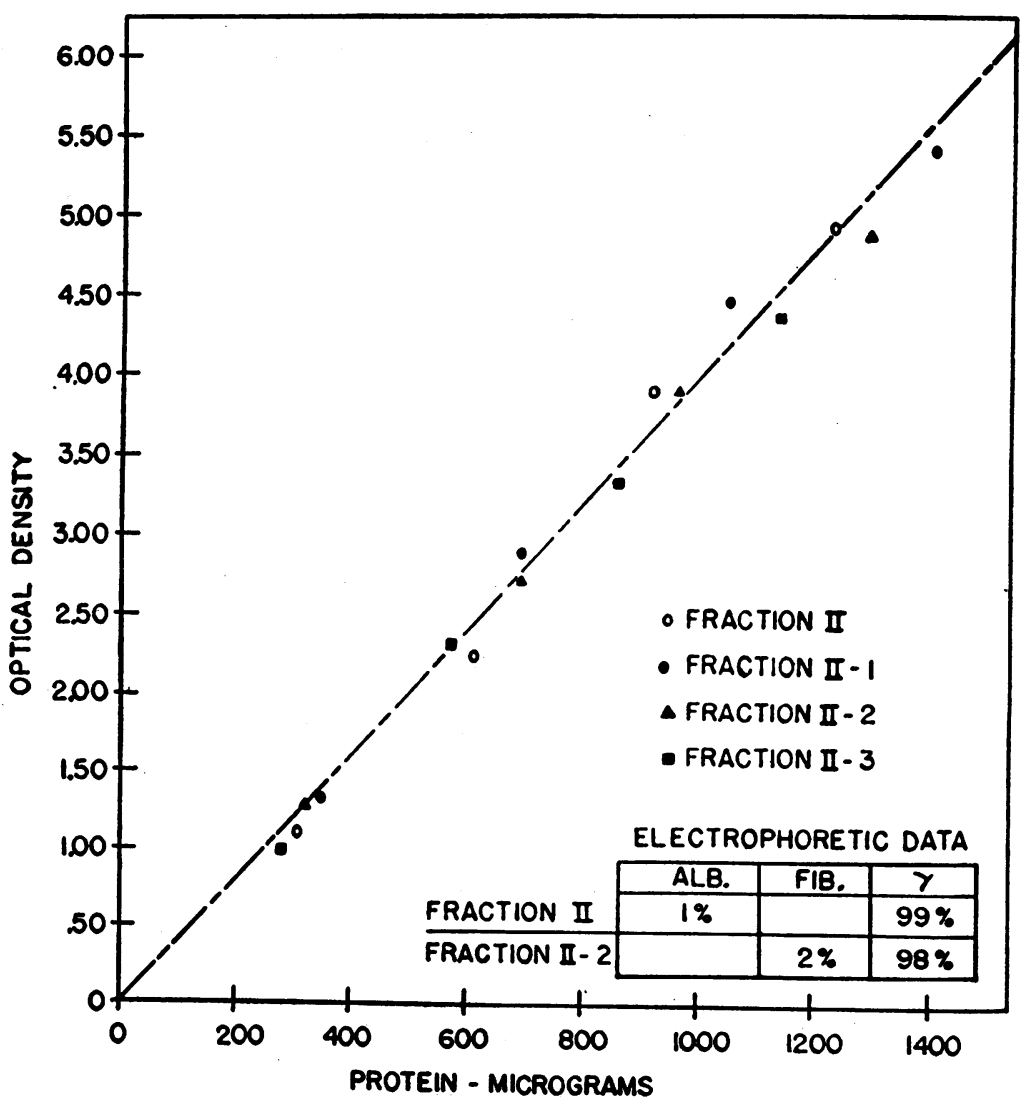

Fig. 1. Photometric Data for Gamas Globulin (Fraction II) and its Subfractions (Fractions II-1, II-2 aNd II-3) 


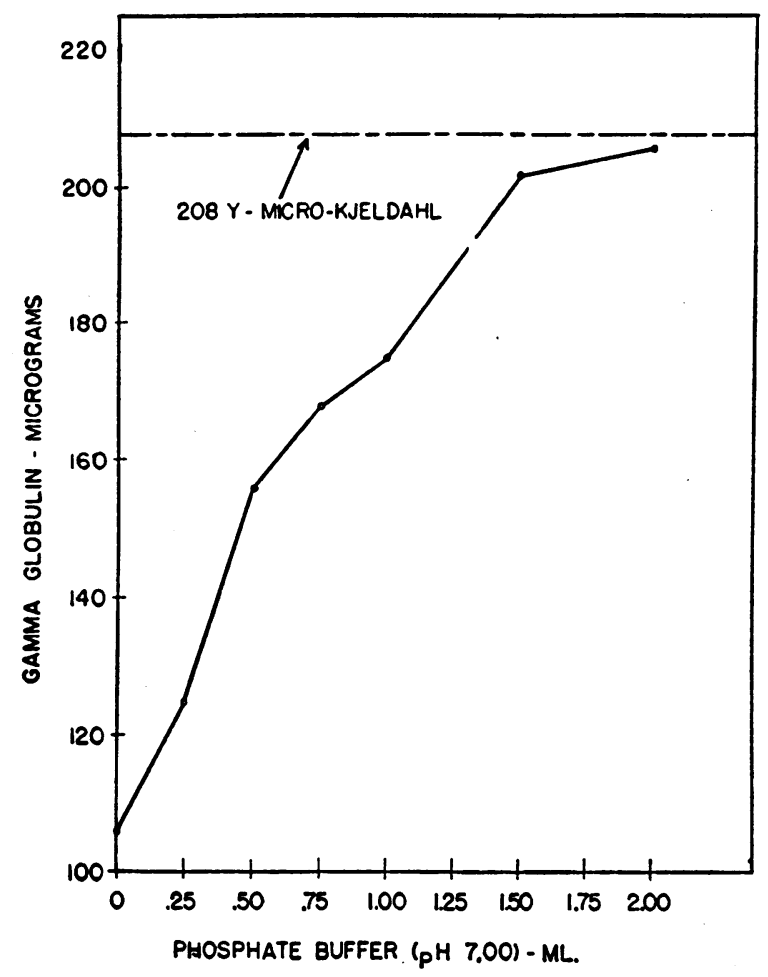

Fig. 2. EfFect of Variation of the Amount of Phosphate (0.1 M) on the Quantitative Flocculation Method for Gamma Globulin

4. Effect of variation of the time of standing at $37.5^{\circ}$. From a large series of preliminary experiments it was found that the temperature at which the flocculation occurs determines to a large extent the rate of flocculation. At room temperature $\left(25^{\circ}\right)$ the rate of flocculation is rather small so that little flocculation occurs within an hour. This rate increases markedly with increasing temperature so that at $37.5^{\circ}$, gamma globulin in the range of 100 to $1000 \mu \mathrm{g}$. is completely flocculated after approximately 30 minutes standing or longer. Higher temperatures were not employed to avoid the possibility of denaturation of various protein fractions. The results obtained for the effect of variation of time of standing at $37.5^{\circ}$ on quantitative flocculation of the gamma globulin from solution is shown in Figure 5.

5. Effect of variation of $p H$ of phosphate buffer on the quantitative flocculation of gamma globulin and other protein fractions from solution. Employing the quantitative flocculation-ninhydrin procedure described above, a large number of experiments were performed with standard gamma globulin solutions to determine the effect of small variations of $\mathrm{pH}$ in the vicinity of the reported isoelectric point $(15,23)$, i.e., $\mathrm{pH}$ 7.3. The values given in Table I give the results obtained at $\pm 0.7 \mathrm{pH}$ units from the isoelectric point. Although the best quantitative results are obtained for $\mathrm{pH} 7.00$, the values obtained for pH 8.00 were sufficiently quantitative to warrant an in-

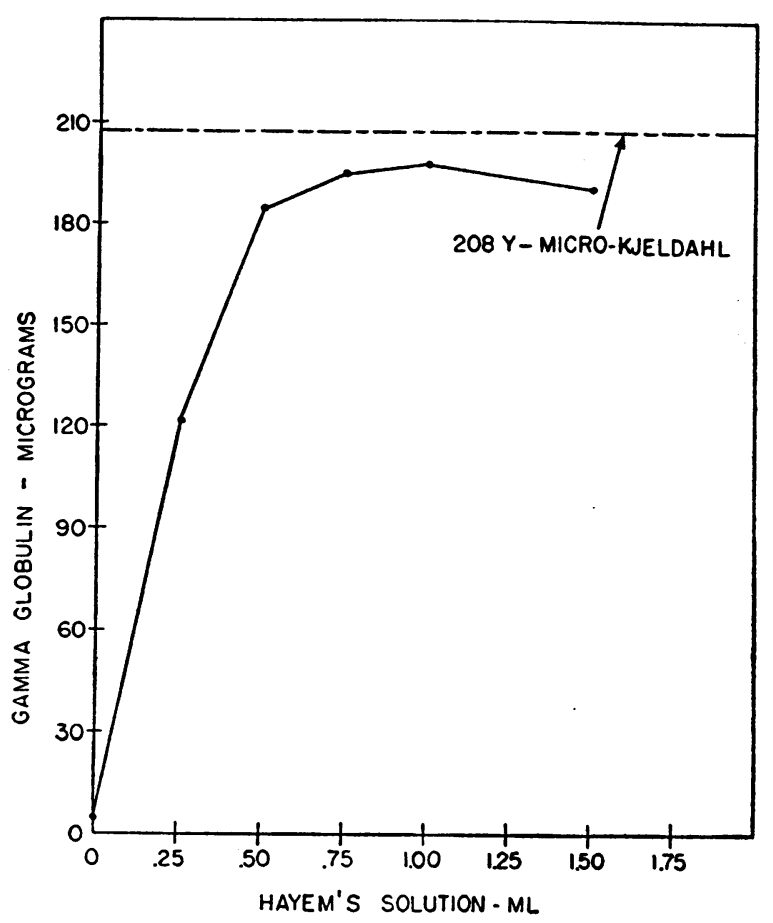

Fig. 3. Effect of Variation of the Amount of Hayem's Solution on the Quantitative Flocculation Method for Gamma Globulin

vestigation of the effect of $\mathrm{pH}$ variation on the flocculation of the other major protein fractions. As can be observed from the data in Table $I$, minimum interference from the other fractions also occurs at pH 7.00.

\section{Studies of the effect of the presence of other protein fractions on the quantitative determination of gamma globulin by the flocculation-ninhydrin procedure}

The fractionation of human plasma by Cohn and his collaborators (12-15) and Edsall (11) has made possible the preparation and characterization of many of the protein components of human plasma. With their original ethanol-water separation technique, human plasma was fractionated into eight major components. The proportion of each component present in the original plasma, and the electrophoretic composition of each fraction, are described in an article by Oncley, Scatchard, and Brown (32). It was these fractions, rather than those prepared with a later fractionation procedure (15), that were investigated for their effect on the quantitative flocculation-ninhydrin method for gamma globulin. In addition a number of subfractions of Fraction II, i.e., II-1, II-2 and II-3, were also determined with this procedure. The electrophoretic data on the bottom of each table are those actually determined on the particular fraction investigated, or those from a similar fraction, as determined at the University Laboratory of Physical Chemistry of the Harvard University Medical School. 


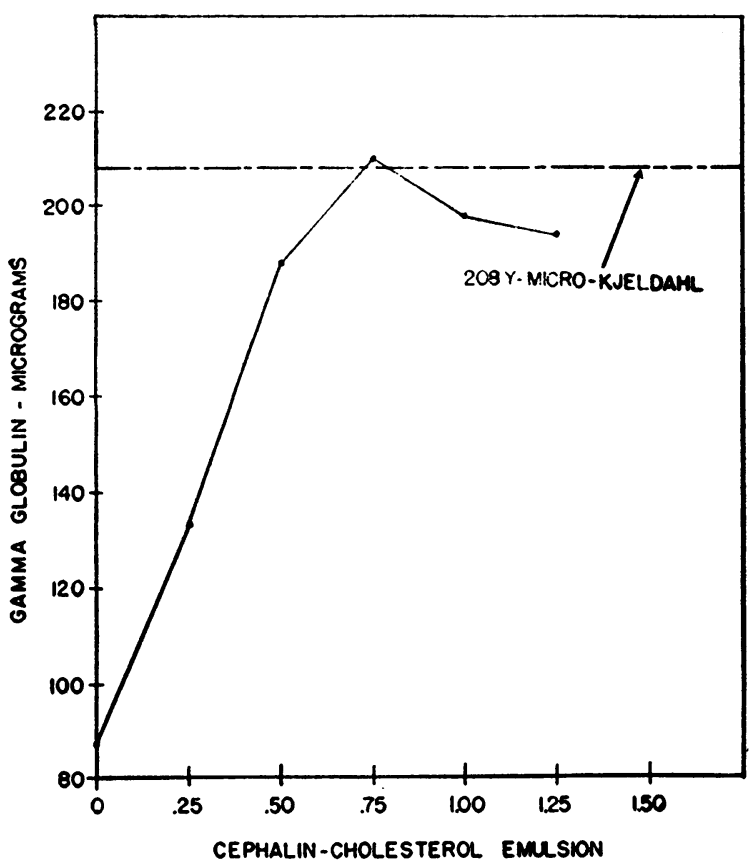

(ML.)

Fig. 4. Effect of Variation of the Amount of the Cephalin-Cholesterol Emulsion on the Quantttative Flocculation Method for Gamma Globulin

Employing the quantitative procedure for gamma globulin described above, mixtures of gamma globulin with each of the other protein fractions, i.e., $\mathrm{V}$ (albumin), IV-1, IV-4, III-0, III and I (fibrinogen) were determined as if the protein mixtures were pure gamma globulin solutions. The ratio of the particular fraction being

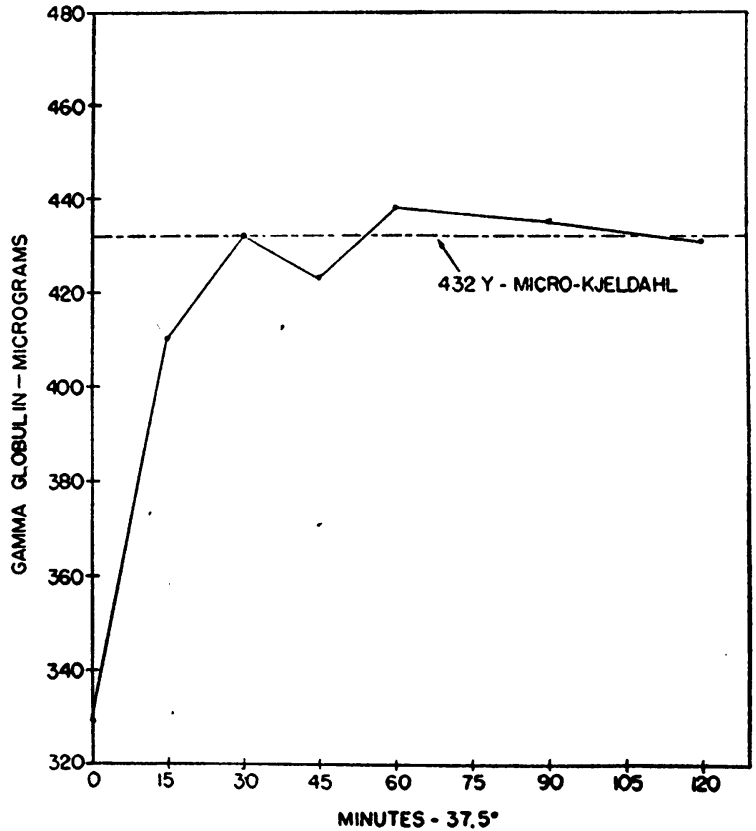

Fig. 5. Effect of the Variation of the Time of Standing at $37.5^{\circ}$ on the Quantitative Flocculation Method for Gamma Globulin

tested to the gamma globulin present was varied so as to include the ratio in which these components are present in normal plasma as given in Table VIII. The results obtained in these runs are given in Tables II through VII inclusive. The data on the gamma globulin subfractions are included in Figure 1.

TABLE I

Effect of $p H$ variation on flocculation of Cohn's protein fractions

\begin{tabular}{|c|c|c|c|c|c|c|c|c|c|}
\hline & 1 & 2 & 3 & 4 & 5 & 6 & 7 & 8 & 9 \\
\hline Protein fraction & $\begin{array}{c}\mathrm{pH} \\
6.60 \\
\text { present }\end{array}$ & $\begin{array}{c}\mathrm{pH} \\
6.60 \\
\text { found }\end{array}$ & $\begin{array}{c}\% \\
\text { recovered }\end{array}$ & $\begin{array}{c}\text { pH } \\
7.00 \\
\text { present }\end{array}$ & $\begin{array}{c}\mathrm{pH} \\
7.00 \\
\text { found }\end{array}$ & $\begin{array}{c}\% \\
\text { recovered }\end{array}$ & $\begin{array}{c}\mathrm{pH} \\
8.00 \\
\text { present }\end{array}$ & $\begin{array}{c}\mathrm{pH} \\
8.00 \\
\text { found }\end{array}$ & $\begin{array}{c}\% \\
\text { recovered }\end{array}$ \\
\hline $\begin{array}{l}\text { Fraction II } \\
\text { (Gamma globulin-99\%) }\end{array}$ & $\begin{array}{l}\mu 8 . \\
224 \\
448\end{array}$ & $\begin{array}{l}\mu g . \\
138 \\
290\end{array}$ & $\begin{array}{l}62 \\
65\end{array}$ & $\begin{array}{r}\mu g . \\
219 \\
432\end{array}$ & $\begin{array}{l}\text { ug. } \\
216 \\
432\end{array}$ & $\begin{array}{r}99 \\
100\end{array}$ & $\begin{array}{l}\mu g . \\
219 \\
432\end{array}$ & $\begin{array}{r}\mu 8 . \\
188 \\
406\end{array}$ & $\begin{array}{l}84 \\
91\end{array}$ \\
\hline $\begin{array}{l}\text { Fraction I } \\
\text { (Fibrinogen [61\%] and } \\
\text { antihemophilic globulin) }\end{array}$ & 125 & 25 & 20 & 62.5 & 6.3 & 10.1 & 125 & 37.5 & 30 \\
\hline $\begin{array}{l}\text { Fraction IV-1 } \\
\left(\text { Alpha }_{1}, \text { alpha }_{2}, \text { beta }_{1}\right)\end{array}$ & 189 & 8 & 4.2 & 189 & 3.7 & 2.0 & 189 & 91 & 48 \\
\hline $\begin{array}{l}\text { Fraction IV-4 } \\
\text { (Albumin, alpha, alpha, } \\
\left.\text { beta }_{1}\right)\end{array}$ & 405 & 6 & 1.5 & 405 & 5.1 & 1.3 & 405 & 317 & 78.2 \\
\hline $\begin{array}{l}\text { Fraction V } \\
\text { (Albumin }-95 \%)\end{array}$ & 900 & 6 & 0.67 & 900 & 20 & 2.2 & 900 & 743 & 82.5 \\
\hline
\end{tabular}




\section{DISCUSSION OF RESULTS}

Study of the various factors which influence the quantitative flocculation-ninhydrin reaction for gamma globulin, as shown in Figures 2 to 5 inclusive, prove that once a critical minimum level of a factor is exceeded, a further increase in the amount of that factor has little influence on the accuracy of the method. Except for the case of the cephalin-cholesterol emulsion, where a definite maximum is indicated, the experimental factor chosen was sufficiently in excess of this critical value to avoid any possibility of error from this source.

Once these critical values were determined the application of the method to the quantitative determination of human gamma globulin (Cohn's Fraction II) was a relatively simple matter. However, quantitative results cannot be obtained unless the precipitated complex is thoroughly washed with anhydrous ether to remove any excess emulsion. A minimum of at least two ether washings was found essential for this purpose.

The data in Figures 3 and 4 indicate that the $\mathrm{Hg}^{++}$ion in Hayem's solution plays a more important role in the flocculation of gamma globulin from solution than does the cephalin-cholesterol emulsion alone. However, both are necessary for quantitative results under the given experimental conditions.

Analysis of the complex proves that cholesterol is firmly bound to the protein and is not removed

TABLE II

Effect of albumin (Fraction $V$ ) on quantitative flocculation method for gamma globulin (Fraction II)

\begin{tabular}{|c|c|c|c|c|c|}
\hline$\underset{\text { present }}{\text { Albumin }}$ & $\begin{array}{l}\text { Gamma } \\
\text { globulin } \\
\text { present }\end{array}$ & $\frac{\text { Albumin }}{\underset{\substack{\text { Gamma glob. } \\
\text { present }}}{ }}$ & $\begin{array}{l}\text { Esti- } \\
\text { mated } \\
\text { gamma } \\
\text { globulin } \\
\text { recovered }\end{array}$ & Error & Remarks \\
\hline $\begin{array}{r}244 \\
487 \\
732 \\
1,220 \\
1,750\end{array}$ & $\begin{array}{l}221 \\
221 \\
221 \\
221 \\
221\end{array}$ & $\begin{array}{l}1.10 \\
2.20 \\
3.30 \\
5.52 \\
7.72\end{array}$ & $\begin{array}{l}213 \\
216 \\
226 \\
236 \\
242\end{array}$ & $\begin{array}{r}-3.6 \\
-2.3 \\
+2.3 \\
+6.8 \\
+9.5\end{array}$ & $\begin{array}{l}\text { Micro-Kjel- } \\
\text { dahl and } \\
\text { Ninhydrin } \\
\text { Ninhydrin } \\
\text { Ninhydrin } \\
\text { Ninhydrin } \\
\text { Ninhydrin } \\
\text { Ninhydrin }\end{array}$ \\
\hline
\end{tabular}

Electrophoretic data-albumin (Fraction V)

$\begin{array}{cccc}\text { Albumin } & \text { Alphas } & \text { Alphaz } & \text { Betai } \\ 95.5 \% & 2 \% & 1 \% & 0.5 \%\end{array}$

TABLE III

Effect of Fraction IV-1 on quantitative flocculation method for gamma globulin (Fraction II)

\begin{tabular}{|c|c|c|c|c|c|}
\hline $\begin{array}{c}\text { Fraction } \\
\text { IV-1 } \\
\text { present }\end{array}$ & $\begin{array}{c}\text { Gamma } \\
\text { globulin } \\
\text { present }\end{array}$ & 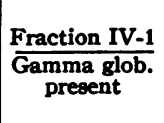 & $\begin{array}{c}\text { Esti- } \\
\text { mated } \\
\text { gamma } \\
\text { globulin } \\
\text { recovered }\end{array}$ & Error & Remarks \\
\hline$\mu g$. & $\begin{array}{c}\text { нg. } \\
199\end{array}$ & & 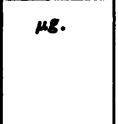 & $\%$ & $\begin{array}{l}\text { Micro-Kjel- } \\
\text { dahl and } \\
\text { Ninhydrin }\end{array}$ \\
\hline $\begin{array}{l}107 \\
214 \\
322 \\
535 \\
749\end{array}$ & $\begin{array}{l}199 \\
199 \\
199 \\
199 \\
199\end{array}$ & $\begin{array}{l}0.54 \\
1.08 \\
1.62 \\
2.69 \\
3.76\end{array}$ & $\begin{array}{l}185 \\
206 \\
215 \\
188 \\
204\end{array}$ & $\begin{array}{l}-7.0 \\
+1.0 \\
+1.1 \\
-5.5 \\
+1.0\end{array}$ & $\begin{array}{l}\text { Ninhydrin } \\
\text { Ninhydrin } \\
\text { Ninhydrin } \\
\text { Ninhydrin } \\
\text { Ninhydrin }\end{array}$ \\
\hline
\end{tabular}

$\begin{array}{ccc}\text { Electrophoretic data-Fraction } I V-1 \\ \text { Alphas } & \text { Alphas } & \text { Betas } \\ 77 \% & 17 \% & 5 \%\end{array}$

by the ether washings. The exact quantitative composition of this complex is as yet unknown and is being investigated not only for gamma globulin but for the other protein fractions as well. It is sufficient for analytical purposes that the gamma globulin is removed from solution quantitatively and in a form; that is, as part of a complex, which can be easily centrifuged, washed and analyzed all in the original tube. The overall accuracy of such a procedure is $\pm 5 \%$ for 100 to $1,000 \mu \mathrm{g}$. of gamma globulin and the optical density values over this range follow the Bouger-Lambert-Beer Law.

The method does not differentiate between gamma globulin (Fraction II) and its subfractions (II-1, II-2 and II-3) and in that respect confirms the findings of Jager and his coworkers (23) and of Kabat and Murray (33) who found these fractions to be immunochemically homogeneous although according to the former investigators these subfractions are inhomogeneous with the ultra-centrifuge and contain particles of different electrophoretic mobility. Cann, Brown, Kirkwood and Hink (34) have separated human gamma globulin into four electrophoretically unique fractions by their electrophoresis-convection technique. In spite of such differences these fractions are all true gamma globulins and any variation in their relative proportions will have no effect on the determination of the total gamma globulin content of a biological fluid by the flocculation-ninhydrin procedure. 
TABLE IV

Effect of Fraction IV-4 on quantitative flocculation method for gamma globulin (Fraction II)

\begin{tabular}{|c|c|c|c|c|c|}
\hline $\begin{array}{c}\text { Fraction } \\
\text { IV-4 } \\
\text { present }\end{array}$ & $\begin{array}{l}\text { Gamma } \\
\text { globulin } \\
\text { present }\end{array}$ & $\frac{\text { Fraction IV-4 }}{\substack{\text { Gamma glob. } \\
\text { present }}}$ & $\begin{array}{c}\text { Esti- } \\
\text { mated } \\
\text { gamma } \\
\text { globulin } \\
\text { recovered }\end{array}$ & Error & Remarks \\
\hline $\begin{array}{r}322 \\
644 \\
966 \\
1,610\end{array}$ & $\begin{array}{l}199 \\
199 \\
199 \\
199\end{array}$ & $\begin{array}{l}1.62 \\
3.24 \\
4.85 \\
8.08\end{array}$ & $\begin{array}{l}183 \\
212 \\
238 \\
230\end{array}$ & $\begin{array}{r}-8.0 \\
+6.5 \\
+19.5 \\
+15.6\end{array}$ & $\begin{array}{l}\text { Micro-Kjel- } \\
\text { dahl and } \\
\text { Ninhydrin } \\
\text { Ninhydrin } \\
\text { Ninhydrin } \\
\text { Ninhydrin } \\
\text { Ninhydrin }\end{array}$ \\
\hline
\end{tabular}

Electrophoretic data-Fraction IV-4

$\begin{array}{ccccc}\text { Albumin } & \text { Alphas } & \text { Alphas } & \text { Betas } & \text { Betas } \\ 26 \% & 10 \% & 28 \% & 34 \% & 3 \%\end{array}$

From the data in Table $\mathrm{I}$ it is apparent that accurate control of $\mathrm{pH}$ by means of buffers is not only important for quantitative results with gamma globulin itself, but is especially important where gamma globulin is to be determined in the presence of considerable amounts of the other protein fractions, e.g., biological fluids. This is especially apparent in the case of albumin where a change of one $\mathrm{pH}$ unit, i.e., from 7.00 to 8.00 , causes an increase in the amount of protein flocculated of some $80 \%$ as compared to that initially present. Main-

TABLE $v$

Effect of Fraction III-O* on quantitative flocculation method for gamma globulin (Fraction II)

\begin{tabular}{|c|c|c|c|c|c|}
\hline $\begin{array}{l}\text { Fraction } \\
\text { Int-0 } \\
\text { present }\end{array}$ & $\begin{array}{l}\text { Gamma } \\
\text { globulin } \\
\text { present }\end{array}$ & $\frac{\text { Fraction III-0 }}{\underset{\text { present }}{\text { Gamma glob. }}}$ & $\begin{array}{c}\text { Esti- } \\
\text { mated } \\
\text { gamma } \\
\text { globulin } \\
\text { recovered }\end{array}$ & Error & Remarks \\
\hline$\mu g$. & $\begin{array}{l}\text { Mg. } \\
155\end{array}$ & & $\mu g$. & $\%$ & $\begin{array}{c}\text { Micro-Kjel- } \\
\text { dahl and } \\
\text { Ninhydrin }\end{array}$ \\
\hline $\begin{array}{r}53 \\
106 \\
159 \\
212\end{array}$ & $\begin{array}{l}155 \\
155 \\
155 \\
155\end{array}$ & $\begin{array}{l}0.34 \\
0.68 \\
1.02 \\
1.36\end{array}$ & $\begin{array}{l}213 \\
219 \\
229 \\
238\end{array}$ & $\begin{array}{l}+37.4 \\
+41.3 \\
+47.7 \\
+53.5\end{array}$ & $\begin{array}{l}\text { Ninhydrin } \\
\text { Ninhydrin } \\
\text { Ninhydrin } \\
\text { Ninhydrin }\end{array}$ \\
\hline
\end{tabular}

\begin{tabular}{lccc}
\multicolumn{5}{c}{ Electrophoretic data-Fraction } & III-0 \\
Alpha & Beta & Gamma & Fibrin. \\
$\mathbf{8 . 3 \%}$ & $78.5 \%$ & $5.0 \%$ & $\mathbf{8 . 3 \%}$
\end{tabular}

- According to personal communication from Dr. L. D. Wojcik of the Harvard University Laboratory of Physical Chemistry, the Fraction III-0 used in these experiments is composed chiefly of beta-lipoprotein with a small amount of beta globulin.

† From data by Oncley, Scatchard, and Brown (32).
TABLE VI

Effect of Fraction III on quantitative flocculation method for gamma globulin (Fraction II)

\begin{tabular}{|c|c|c|c|c|c|}
\hline $\begin{array}{l}\text { Fraction } \\
\text { III } \\
\text { present }\end{array}$ & $\begin{array}{c}\text { Gamma } \\
\text { globulin } \\
\text { present }\end{array}$ & $\frac{\text { Fraction III }}{\underset{\text { present }}{\text { Gamma glob. }}}$ & $\begin{array}{c}\text { Esti- } \\
\text { mated } \\
\text { gamma } \\
\text { globulin } \\
\text { recovered }\end{array}$ & Error & Remarks \\
\hline Mg. & $\begin{array}{c}\mu g . \\
155\end{array}$ & & $\mu g-$ & $\%$ & $\begin{array}{l}\text { Micro-Kjel- } \\
\text { dal and } \\
\text { Ninhydrin }\end{array}$ \\
\hline $\begin{array}{l}106 \\
212 \\
318 \\
424\end{array}$ & $\begin{array}{l}155 \\
155 \\
155 \\
155\end{array}$ & $\begin{array}{l}0.69 \\
1.38 \\
2.07 \\
2.76\end{array}$ & $\begin{array}{l}240 \\
298 \\
346 \\
396\end{array}$ & $\begin{array}{r}+54.8 \\
+92.5 \\
+123 \\
+155\end{array}$ & $\begin{array}{l}\text { Ninhydrin } \\
\text { Ninhydrin } \\
\text { Ninhydrin } \\
\text { Ninhydrin }\end{array}$ \\
\hline
\end{tabular}

Electrophoretic data-Fraction III*

$\begin{array}{cccc}\text { Alpha } & \text { Beta } & \text { Fibrin. } & \text { Gamma } \\ \mathbf{7 . 0 \%} & \mathbf{5 5 . 6 \%} & \mathbf{2 6 . 2 \%} & \mathbf{1 1 . 2 \%}\end{array}$

* From data by Oncley, Scatchard, and Brown (32).

tenance of the $\mathrm{pH}$ below 7.00 gives poorer recoveries of gamma globulin but lessens the interference from albumin. In view of the fact that the albumin fraction inhibits the cephalin-cholesterol flocculation reaction with gamma globulin (1) its elimination or neutralization is a most important consideration.

The data in Tables II to VII deal with the effect of all the other fractions, as separated by Cohn's Method 6, which constitute the whole plasma. The non-interfering fractions are Fractions V, IV-1, IV-4 and VI. The latter fraction was not tested and is listed as a non-interfering fraction because it contains only a small amount of protein

TABLE VII

Effect of Fraction I (fibrinogen and antihemophilic globulin) on quantitative flocculation method for gamma globulin (Fraction II)

\begin{tabular}{|c|c|c|c|c|c|}
\hline $\begin{array}{l}\text { Fraction } \\
\text { I } \\
\text { present }\end{array}$ & $\begin{array}{c}\text { Gamma } \\
\text { globulin } \\
\text { present }\end{array}$ & $\frac{\text { Fraction I }}{\underset{\text { present }}{\text { Gamma glob. }}}$ & $\begin{array}{l}\text { Esti- } \\
\text { mated } \\
\text { gamma } \\
\text { globulin } \\
\text { recovered }\end{array}$ & Error & Remarks \\
\hline Mg. & $\begin{array}{c}\mu 8 . \\
240\end{array}$ & & $\mu \mathrm{g}$. & $\%$ & $\begin{array}{c}\text { Micro-Kjel- } \\
\text { dahl and } \\
\text { Ninhydrin }\end{array}$ \\
\hline $\begin{array}{l}176.5 \\
253 \\
330 \\
06\end{array}$ & $\begin{array}{l}240 \\
240 \\
240 \\
240\end{array}$ & $\begin{array}{l}0.32 \\
0.64 \\
0.96 \\
1.27\end{array}$ & $\begin{array}{l}266 \\
288 \\
320 \\
350\end{array}$ & $\begin{array}{l}+10.8 \\
+20.0 \\
+33.3 \\
+46.0\end{array}$ & $\begin{array}{l}\text { Ninhydrin } \\
\text { Ninhydrin } \\
\text { Ninhydrin } \\
\text { Ninhydrin }\end{array}$ \\
\hline
\end{tabular}

Electrophoretic data-Fraction I

$\begin{array}{ccccc}\text { Albumin } & \text { Alphas } & \text { Beta1 } & \text { Fibrin. } & \text { Gamma } \\ 7 \% & 8 \% & 15 \% & 61 \% & 9 \%\end{array}$


which is mostly albumin. From the electrophoretic viewpoint the non-interfering fractions are either rich in albumin or alpha protein and contain less than $37 \%$ of beta globulin. At the ratio of the particular protein fraction to gamma globulin found in normal plasma (see Table VIII), these fractions when run together with gamma globulin, do not give values more than $5 \%$ greater than that due to gamma globulin alone.

The interfering fractions are I, III and III- -0 and the amounts of each present in normal plasma and their ratio to gamma globulin are also given in Table VIII. These fractions are rich in fibrinogen or beta globulin (or beta lipoprotein) and introduce considerably positive errors when run together with gamma globulin. As shown in Tables V-VII these errors decrease rapidly with decreasing protein fraction/gamma globulin ratio, and indicate the possibility of eliminating such errors by reducing the concentrations of these components by salt fractionation prior to the flocculation procedure.

Table VIII contains data for the amount of each protein fraction present in normal plasma, the ratio of each fraction to the gamma globulin present in plasma and a summary of the predicted errors for plasma and sera as calculated from the preceding tables, Tables II to VII inclusive. In making these calculations it was assumed that any gamma globulin shown to be present in the electrophoretic data, given at the bottom of each table, would be included in the analysis of sera or plasma for gamma globulin with the flocculation-ninhydrin method. In addition it was assumed that any fibrinogen present in plasma would be removed as an interfering factor during the blood-clotting process and would not be present in sera. On the basis of these assumptions it was calculated that an error of about $+82 \%$ would occur if plasma were analyzed by the flocculation-ninhydrin method for gamma globulin. The error for sera was estimated to be about $+48 \%$.

The elimination of these large positive errors for serum gamma globulin determinations, the comparison of the quantitative flocculation-ninhydrin method with electrophoretic data on the same sera, and the evaluation of a new clinical entity, the $\frac{\text { (total serum flocculation-ninhydrin value) }}{\text { (globulin clot flocculation-ninhydrin value) }}$ for both normal and disease cases is discussed in the

TABLE'VIII

Summation of data on the effect of Cohn's protein fractions on the quantitative flocculation method for gamma globulin (Fraction II)

\begin{tabular}{|c|c|c|c|c|}
\hline Plasma protein fraction & $\begin{array}{c}\text { Estimated amount } \\
\text { of protein fraction } \\
\text { in } 1 \mathrm{ml} \text {. of a } 1: 50 \\
\text { diltn. of normal } \\
\text { plasma* }\end{array}$ & $\frac{\text { Prot. fraction }}{\text { Gamma glob. }}$ & $\begin{array}{l}\text { Predicted errort } \\
\text { from previous } \\
\text { data-plasma }\end{array}$ & Remarks \\
\hline $\begin{array}{l}\text { Fraction II } \\
\text { (Gamma globulin) } \\
\text { Fraction I } \\
\quad \text { (Fibrinogen, etc.) } \\
\text { Fraction III } \\
\text { (Fibrinogen, beta globulin, etc.) } \\
\text { Fraction III-0 } \\
\text { (Beta lipoprotein, beta globulin) } \\
\text { Fraction IV-1 } \\
\quad \text { (Alpha1 and alpha, globulins) } \\
\text { Fraction IV-4 } \\
\quad \text { (Albumin, alpha, and beta } \\
\text { globulins) } \\
\text { Fraction V } \\
\text { (Albumin) } \\
\text { Fraction VI } \\
\text { (Albumin, etc.) }\end{array}$ & $\begin{array}{r}80 \\
108 \\
104 \\
116\end{array}$ & $\begin{array}{l}0.67 \\
0.98 \\
0.87 \\
0.97\end{array}$ & $\begin{array}{l}\quad \mu 8 . \\
\pm 6 \\
+(5-17) \\
\text { Sera }=0 \\
+(34-43) \\
\text { Sera }=+(17-25) \\
+(42-54) \\
\text { Sera }=+(31-43) \\
0 \\
0 \\
0 \\
0\end{array}$ & $\begin{array}{l}\text { With colorimetric ninhydrin } \\
\text { method. } \\
\text { Contains } 9 \% \text { gamma glob. fibrin- } \\
\text { ogen removed during blood } \\
\text { clotting. } \\
\text { Contains } 11.2 \% \text { gamma and } \\
26.2 \% \text { fibrinogen. } \\
\text { Contains } 5 \% \text { gamma and } 8.3 \% \\
\text { fibrinogen. } \\
\text { Presence of these fractions, at in- } \\
\text { dicated ratio, gives gamma globu- } \\
\text { lin values within experimental } \\
\text { limits of error of method. }\end{array}$ \\
\hline
\end{tabular}

* Calculated from data by Oncley, Scatchard, and Brown(32).

$\dagger$ Predicted error: for Plasma $=+87 \mu \mathrm{g}$. (aver.) or $+82.5 \%$; for Sera $=58 \mu \mathrm{g}$. (aver.) or $+48.3 \%$. 
subsequent paper. The application of the general principles of quantitative protein flocculation for the microdetermination of other electrophoretic components besides gamma globulin, is presently being investigated in this laboratory, e.g., albumin and fibrinogen.

\section{SUMMARY}

1. A simple accurate photometric microprocedure for the quantitative determination of electrophoretically pure gamma globulin (Cohn's Fraction II) in the range of 100 to $1,000 \mu \mathrm{g}$. of protein, has been described.

2. The principle of the method involves the quantitative flocculation from solution of the gamma globulin with a cephalin-cholesterol emulsion in the presence of Hayem's solution and determination of the protein content of the ether washed precipitate photometrically with the ninhydrin reaction, all in the same tube.

3. The various factors which influence the quantitative flocculation-ninhydrin reaction, e.g., $\mathrm{pH}$, temperature, time, concentration of the reagents, etc., have been carefully studied and controlled.

4. Subfractions of gamma globulin gave results which were identical with those obtained with the original whole Fraction II.

5. The effect of the presence of each of Cohn's other protein fractions (Method 6) which constitute whole plasma, have been investigated for their effect on the quantitative determination of gamma globulin. It was found experimentally that only those fractions which are rich in fibrinogen, beta globulin or beta lipoprotein interfere.

\section{ACKNOWLEDGMENTS}

The authors wish to acknowledge their gratitude to Dr. Joseph Steigman of the Department of Analytical Chemistry of the Polytechnic Institute of Brooklyn and to Dr. E. A. Kabat of the College of Physicians and Surgeons of the Columbia University Medical School for their helpful advice and criticism during the course of this work. We are grateful to Dr. Bruno W. Volk, Director of Laboratories of the Jewish Sanitarium and Hospital for Chronic Diseases, for his aid and encouragement of this work, and to Mrs. Jennie Herbst for typing and editing of the manuscript.

\section{REFERENCES}

1. Maclagan, N. F., Flocculation tests; chemical and clinical significance. Brit. Med. J., 1948, 2, 892.

2. Stern, K. G., and Reiner, M., Electrophoresis in medicine. Yale J. Biol. \& Med., 1946, 19, 67.
3. Luetscher, J. A., Jr., Biological and medical applications of electrophoresis. Physiol. Rev., 1947, 27, 621.

4. Gutman, A. B., Plasma proteins in disease, in Advances in Protein Chemistry, edited by Anson, M. L., and Edsall, J. T. Academic Press, Inc., New York, 1948, Vol. IV, p. 155.

5. Jager, B. V., and Nickerson, M., Simple quantitative chemical method for estimating gamma globulin in human serum. J. Biol. Chem., 1948, 173, 683.

6. Wolfson, W. Q., Cohn, C., Calvary, E., and Ichiba, F., Studies in serum proteins; rapid procedure for estimation of total protein, true albumin, total globulin, alpha globulin, beta globulin and gamma globulin, in $1.0 \mathrm{ml}$. of serum. Am. J. Clin. Path., 1948, 18, 723.

7. Kibrick, A. C., and Blonstein, M., Fractionation of serum into albumin and alpha, beta and gamma globulin by sodium sulphate. J. Biol. Chem., 1948, 176, 983.

8. de la Huerga, J., and Popper, H., Estimation of serum gamma globulin concentration by turbidimetry. J. Lab. \& Clin. Med., 1950, 35, 459.

9. de la Huerga, J., Popper, H., Franklin, M., and Routh, J. I., Comparison of the results of gamma globulin and zine sulphate turbidity test with electrophoretic determination of the gamma globulins. J. Lab. \& Clin. Med., 1950, 35, 466.

10. Pillemer, L., and Hutchinson, M. C., The determination of the albumin and globulin contents of human serum by methanol precipitation. J. Biol. Chem., 1945, 158, 299.

11. Edsall, J. T., The plasma proteins and their fractionation, in Advances in Protein Chemistry, edited by Anson, M. L., and Edsall, J. T. Academic Press, Inc., New York, 1947, Vol. III, p. 383.

12. Cohn, E. J., History of plasma fractionation in Advances in Military Medicine. Little, Brown \& Co., Boston, 1947, Vol. I, Chap. 28, p. 364.

13. Cohn, E. J., Strong, L. E., Hughes, W. L., Jr., Mulford, D. J., Ashworth, J. N., Melin, M., and Taylor, H. L., Preparation and properties of serum and plasma proteins. IV. A system for the separation into fractions of the protein and lipoprotein components of biological tissues and fluids. J. Am. Chem. Soc., 1946, 68, 459.

14. Cohn, E. J., Directions for the Preparation of Prothrombin, Isoagglutinins and Serum Gamma Globulin (Human), Method 9. Mimeographed pamphlet, Lab. Phys. Chem., Harvard U. Medical School, Boston, Revision of July 27, 1945.

15. Cohn, E. J., Gurd, F. R. N., Surgenor, D. M., Barnes, B. A., Brown, R. K., Derouaux, G., Gillespie, J. M., Kahnt, F. W., Lever, W. F., Liu, C. H., Mittelman, D., Mouton, R. F., Schmid, K., and Uroma, E., A system for the separation of the components of human blood: quantitative procedure for the separation of the protein components of human plasma. J. Am. Chem. Soc., 1950, 72, 465. 
16a. Pearsall, H. R., and Chanutin, A., Electrophoretic, nitrogen and lipide analyses of plasma and plasma fractions of healthy young men. Am. J. Med., 1949, 7, 297.

b. Pearsall, H. R., and Chanutin, A., Electrophoretic, nitrogen and lipide analyses of plasma and plasma fractions in disease. Ibid., 301.

17. Lever, W. F., Gurd, F. R. N., Uroma, E., Brown, R. K., Barnes, B. A., Schmid, K, and Schultz, E. L., Chemical, clinical and immunological studies on the products of human plasma fractionation. XL. Quantitative separation and determination of the protein components in small amounts of normal human plasma. J. Clin. Invest., 1951, 30, 99.

18. Gjessing, E. C., and Chanutin, A., Electrophoretic study of plasma and plasma fractions of normal and injured rats. J. Biol. Chem., 1947, 169, 657.

19. Gjessing, E. C., Ludewig, S., and Chanutin, A., Fractionation, electrophoresis and chemical studies of proteins in sera of control and injured dogs. J. Biol. Chem., 1947, 170, 551.

20. Ecker, E. E., and Likover, B., A micromethod for the determination of the albumin-globulin ratio in guinea pig serum. J. Lab. \& Clin. Med., 1947, 32, 1500.

21. Kendall, F. E., Studies on serum proteins. I. Identification of a single serum globulin by immunological means; its distribution in sera of normal individuals and of patients with cirrhosis of the liver and with chronic glomerulonephritis. J. Clin. Invest., 1937, 16, 921.

22a. Kabat, E. A., Glusman, M., and Knaub, V., Quantitative estimation of albumin and gamma globulin in normal and pathologic cerebrospinal fluid by immunochemical methods. Am. J. Med., 1948, 4, 653.

b. Kabat, E. A., Glusman, M., and Knaub, V., Immunochemical estimation of albumin and gamma globulin in normal and pathologic cerebrospinal fluid. Federation Proc., 1948, 7, 306.
23. Jager, B. V., Smith, E. L., Nickerson, M., and Brown, D. M., Immunological and electrophoretic studies on human gamma globulins. J. Biol. Chem., 1948, 176, 1177.

24. Kunkel, H. G., Estimation of alterations of serum gamma globulin by turbidimetric technique. Proc. Soc. Exper. Biol. \& Med., 1947, 66, 217.

25. Schmid, R., The zinc turbidity test and its clinical application. J. Lab. \& Clin. Med., 1950, 36, 52.

26. Saifer, A., Estimation of increased gamma globulin and fibrinogen in cerebrospinal fluid; a serial dilution-flocculation method. J. Lab. \& Clin. Med., 1950, 36, 130.

27. Hanger, F. M., Flocculation of cephalin-cholesterol emulsions by pathological sera. Tr. A. Am. Physicians, 1938, 53, 148.

28. Mandel, E. E., and Paris, D. A., Evaluation of the flocculation test with Hayem's solution. J. Lab. \& Clin. Med., 1949, 34, 653.

29. Moore, S., and Stein, W. H., Photometric ninhydrin method for use in the chromatography of amino acids. J. Biol. Chem., 1948, 176, 367.

30. Markham, R., Steam distillation apparatus suitable for micro-Kjeldahl analysis. Biochem. J., 1942, 36, 790.

31. Dern, R. J., and Pullman, T. N., The accuracy, precision and utility of the syringe as a pipetting device. J. Lab. \& Clin. Med., 1950, 36, 494.

32. Oncley, J. L., Scatchard, G., and Brown, A., Physicalchemical characteristics of certain of the proteins of normal human plasma. J. Phys. \& Coll. Chem., 1947, 51, 184.

33. Kabat, E. A., and Murray, J. P., A comparison of human gamma globulins in their reactivity with rabbit anti-gamma globulin by the quantitative precipitin method. J. Biol. Chem., 1950, 182, 251.

34. Cann, J. R., Brown, R. A., Kirkwood, J. G., and Hink, J. H., Jr., Fractionation of human immune gamma globulin. J. Biol. Chem., 1950, 185, 663. 